\title{
The Snapping Turtle, Chelydra serpentina (Linnaeus 1758) (Testudines: Chelydridae), in the Florida Keys
}

\author{
Michael V. Cove and Andrew S. Maurer
}

Department of Applied Ecology, North Carolina State University, Raleigh, North Carolina 27695, USA (mvcove@ncsu.edu)

$\mathrm{T}$ The Snapping Turtle, Chelydra serpentina (Linnaeus 1758), is native to North America, from southeastern Canada, along the southwestern edge of the Rocky Mountains and throughout the eastern United States (Ernst and Lovich 2009). Although C. serpentina has been observed and studied throughout peninsular Florida, it has never been recorded in the Florida Keys (Krysko et al. 2011).

On 4 February 2013 at 1520 h, we observed an adult Chelydra serpentina (Fig. 1) on Big Pine Key, Monroe County, Florida $\left(24.71912^{\circ} \mathrm{N}, 81.39296^{\circ} \mathrm{W}\right.$, datum WGS84, elev. < $1 \mathrm{~m})$. This individual was observed in a mosquito ditch surrounded by White Mangrove (Laguncularia racemosa) and Buttonwood (Conocarpus erectus) habitat with a scattering of Cordgrass (Spartina sp.) and Smooth Sawgrass (Cladium mariscoides). A digital image was deposited in the Florida Museum of Natural History, University of Florida (UF-Herpetology 174814). The identity of the species was confirmed by Dr. Kenneth L. Krysko.

One week later (11 February 2013) in the same relative location, we observed another $C$. serpentina that was completely covered in filamentous green algae on the shell, head, and tail, and appeared to be slightly larger than the first individual, indicating the presence of multiple individuals in the area. Mosquito ditches might represent the Big Pine Key equivalent of the habitat type best suited for the species, small wetlands with a soft muck bottom and abundant aquatic vegetation (Aresco and Gunzburger 2007). Furthermore, Snapping Turtles frequently travel across dry land and mosquito ditches of the Lower Keys might serve as refugia for this species and its prey during the drier months of the year (Aresco and Gunzburger 2007).

Given the extensive amount of sampling in the Florida Keys over the past century with no prior reports of Chelydra serpentina (Duellman and Schwartz 1958; Lazell 1989; Krysko et al. 2011), we suspect that this species was introduced. Many of the introduced turtles (e.g., Apalone ferox

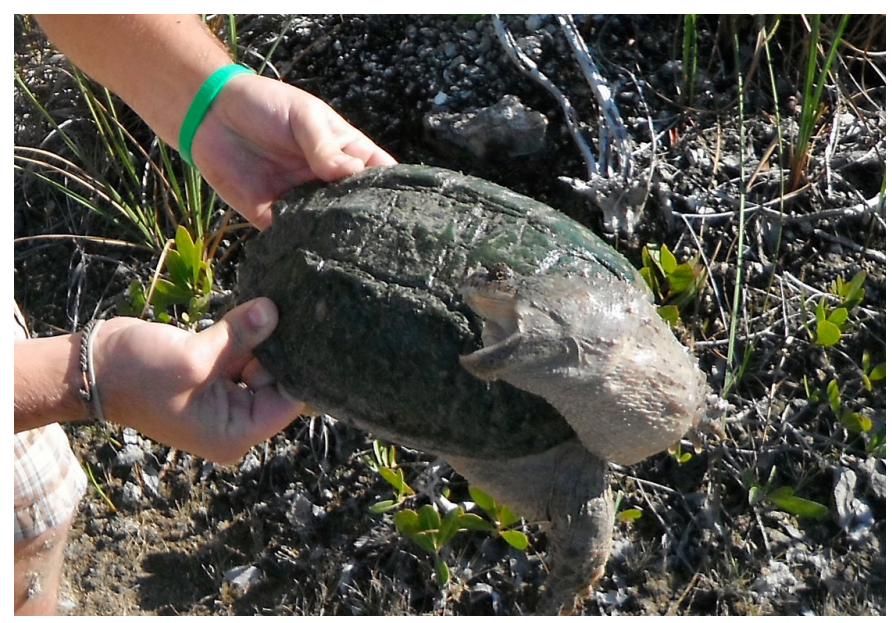

Fig. 1. Snapping Turtle, Chelydra serpentina (UF-Herpetology photographic voucher 174814), at the capture site on Big Pine Key, Monroe County, Florida, on 4 February 2013. Photograph by Andrew S. Maurer.

[Schneider 1783], Pseudemys nelsoni [Carr 1938], Trachemys scripta [Wied-Neuwied 1839]) and fishes (e.g., Colossoma sp., Oreochromis sp.) of the Keys have been found in the Blue Hole on Big Pine Key, where they presumably were released (Lazell 1989; Powell 2012); however, we detected C. serpentina in a much less accessible location. Genetic analyses might further aid in identifying the origin of the individuals in the Keys. The multiple observations suggest the need for further surveys for $C$. serpentina to determine if the species is established in the Lower Keys.

\section{Acknowledgments}

We thank the U.S. Fish and Wildlife Service and specifically the biologists and managers of the Florida Keys National Wildlife Refuges Complex for their continued support and access to the National Key Deer Refuge. Kenneth L. Krysko commented on a previous version of the manuscript. 


\section{Literature Cited}

Aresco, M.J. and M.S. Gunzburger. 2007. Ecology and morphology of Chelydra serpentina in northwestern Florida. Southeastern Naturalist 6:435-448.

Duellman, W.E. and A. Schwartz. 1958. Amphibians and reptiles of southern Florida. Bulletin of the Florida State Museum Biological Sciences 3:182-326.

Ernst, C.H. and J.E. Lovich. 2009. Turtles of the United States and Canada. Johns Hopkins University Press. Baltimore, Maryland.
Krysko, K.L., K.M. Enge, and P.E. Moler. 2011. Atlas of Amphibians and Reptiles in Florida. Final Report, Project Agreement 08013, Florida Fish and Wildlife Conservation Commission, Tallahassee.

Lazell, Jr., J.D. 1989. Wildlife of the Florida Keys, A Natural History. Island Press, Washington, D.C.

Powell, R. 2012. Geographic Distribution: Apalone ferox. Herpetological Review 43:302. 